\title{
(No) More Ears: A Preface to the English-Language Edition
}

All Ears was never intended to be simply a book about current events.

The question "Are they listening to me?"-with which, in 2007 , I opened this second volume of a diptych devoted to listening ${ }^{1}$ - has no doubt always resonated in the hollow of our ears as the very question that opens and orients them. ${ }^{2}$ For what is at stake in it is quite simply the ear of the other that precedes mine.

However, on the path that I decided to follow in order to resume my otological inquiries in the direction of their most immediately ethical and political stakes, we encounter a number of events that marked, at the time when I was writing, a profound and massive transformation of the auditory landscape in which we deliver ourselves to this seemingly so passive and pacific activity: hearing. These were the then recent revelations in Europe about the Echelon network, an inheritance of the Cold War. Since then, this transformation has only intensified and become more evident in a new space (that we could call "post-Snowdenian") where a generalized otographic surveillance appears to have definitively sanctioned the reign of one of James Joyce's obscure characters: 
Earwicker, an emblem of those "big ears" to which we are exposed every second of our lives in the (cyber) world.

The NSA spying on Angela Merkel's phone conversations and on those of two French ministers; Edward Snowden seeking asylum in Russia; user data collected on Google, Facebook, YouTube, Skype: We could all continue the list of facts exposed by the Guardian, the Washington Post, or Le Monde, a list that keeps growing every day. The methods are more and more sophisticated (without knowing anything about them, we have all heard of the surveillance program Prism and the computer system XKeyscore): Espionage has become digital, and as such, to use Deleuze's term, it obeys the logic of control rather than that of disciplinary surveillance to the extent that listening, as a particular sense or sensorial region that can be identified in its difference, appears to dissolve itself in the generalized indexation and machinic auscultation of communication flows. But the wager of this book is that perhaps the paradigm of auditory espionage (this old paradigm to which Earwicker gives his name) allows us better than any other to understand what is happening to us, even if this paradigm appears to be already a thing of the past. It is as if there were more and more earsonly ears, everywhere-even though there are no real ears anymore.

In the face of this simultaneously omnipresent and evasive actuality or virtuality (which constitute the very stakes of what I call, after and following the panopticism described by Foucault, panacousticism), the basic gesture of All Ears was above all archaeological. The book tried to think the epochs and stratifications of overhearing, as well as the genesis of the otological surplus that constitutes it. But the genealogy was shadowed by an apparently contrary or irreconcilable inquiry that concerned the structure rather than the history of auditory espionage: The possibility of this perversion that inhab- 
its listening from the very beginning appeared to me to be what, at the same time, also makes it possible. It is in this sense that the subtitle of the book, The Aesthetics of Espionage, alludes to the figure of the spy simultaneously as a motif or theme in (cinematic, literary, and musical) works of art (in short, in "aesthetic" productions in the common usage of the word), but also as the condition of the possibility of listening in general: Espionage (the ear of the other) could then be understood also and above all in the sense of what we could call, slightly deflecting the Kant of the Critique of Pure Reason, a "transcendental aesthetic" of aurality.

In the end, however, I refrained from putting things in these terms, since the word "transcendental" was not quite right. Rather, we are dealing with something "quasi-transcendental" (as Derrida put it, to whom the book is dedicated in the form of a posthumous homage). Engaged in what is considered to be the (second) oldest profession in the world, the spy forms a part of a (historical or empirical) series of figures of listening. It is one term or one element in the series. At the same time, however, it also accounts for the cause or the possibility of the very series to which it belongs. ${ }^{3}$ Today I would perhaps no longer say this using the same vocabulary, but this was what dictated to me the choice of the subtitle at the time when I was writing All Ears.

Another reason to doubt the good old Kantian term "transcendental" is that if it is true that espionage makes listening possible, at the same time it also makes it impossible. What puts in motion the drive toward surveillance, through which listening becomes the listening that it is, happens to be also what inhibits it and makes it deaf (as I show through Orpheus and Kafka's story "The Burrow"). ${ }^{4}$ The political consequences of this structure extend everywhere today, to the United States as well as to France: When we try to hear everything, we do not hear anything. 
All Ears, therefore, is fundamentally a book about impossible listening. About overhearing as something that is possible only as impossible.

It is on the basis of this auditory aporia that we will see emerge here, I hope, the true stakes that sustain these pages in their urgency (which is not simply their topicality): the question of a responsibility of listening, as I outlined it already in Listen: A History of Our Ears. The reader will find here its necessary further development. 